\title{
Rola prefabrykacji w ksztaltowaniu architektury mieszkaniowej XXI wieku
}

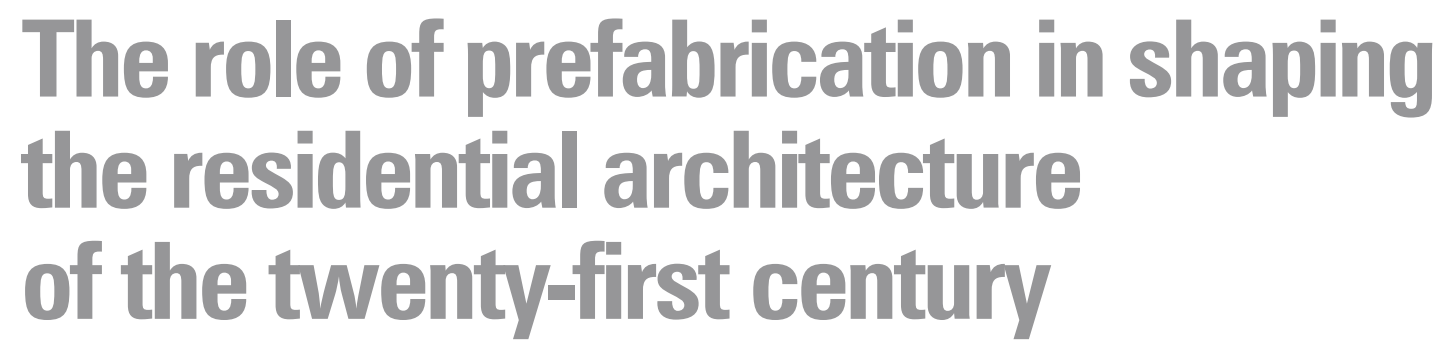

\section{Streszczenie}

Prefabrykacja wpłynęła w znaczy sposób na kształt architektury mieszkaniowej XX wieku, a jej znaczenie nadal nie słabnie. W przeszłości czas eksperymentu przeobraził się w burzliwy okres rozwój technologii, systemów budownictwa i ich odmian. Rolą prefabrykacji było określenie podstawowych standardów mieszkaniowych w zakresie kształtu mieszkań i charakteru zabudowy. Obecnie technologia prefabrykacji betonowej nabiera ponownie znaczenia jako współczesne tworzywo architektoniczne i jest często stosowaną metodą wznoszenia budynków mieszkalnych. Istnieje wiele możliwości jakie tkwią w produkowanych prefabrykowanych komponentach oraz zalet ekonomicznych i technologicznych. Z jednej strony elastyczność i różnorodność projektowanych elementów, z drugiej strony lepsze technologicznie prefabrykaty, w znaczny sposób pozwalają dostosować typizację do współczesnych wymagań użytkowych i estetycznych architektury mieszkaniowej.

\begin{abstract}
Prefabrication had a significant influence on the shape of the residential architecture of the twentieth century and its importance has not diminished. In the past, a time of experimentation changed into a turbulent period of technological advancement and development of construction systems and their types. The role of prefabrication was to define basic housing standards in terms of flat layouts and the character of housing developments. Currently, concrete prefabrication technology is becoming more and more important as a modern architectural material and is a frequently used method of erecting residential buildings. There is considerable potential in prefabricated components as well as economic and technological benefits. On the one hand, there is flexibility and variety of designed elements, and on the other, prefabricated components, which are technologically superior, allow an adjustment of standardisation to contemporary functional and aesthetic requirements of the residential architecture in a significant way.
\end{abstract}

Słowa kluczowe: uprzemysłowienie budownictwa, prefabrykaty, standardy mieszkaniowe, mieszkalnictwo Keywords: industrialisation of construction, prefabricated components, housing standards, housing

\section{Wprowadzenie}

Metody uprzemysłowione budownictwa stały u podstaw formowania architektury mieszkaniowej w XX wieku. Przede wszystkim w przeszłości określały funkcjonujące przez lata standardy mieszkaniowe w zakresie kształtu mieszkań i charakteru zabudowy. Zapewniły Polakom w okresie największego rozwoju tej technologii imponującą liczbę, siedmiu milionów mieszkań w budynkach wielorodzinnych. Obecnie technologia prefabrykacji betonowej nabiera ponownie znaczenia jako współczesne tworzywo architektoniczne i jest coraz częściej stosowaną metodą wznoszenia budynków mieszkalnych. Ze względu na nowe możliwości jej zastosowania nastąpiła istotna zmiana w sposobie myślenia i kształtowania przestrzeni, jako budowie rozwiązań elastycznych do-

\section{Introduction}

Industrialised methods of construction shaped the residential architecture of the twentieth century. First of all, in the past they determined the long-functioning housing standards in terms of flat layouts and the character of housing developments. They provided Poles with an impressive number of seven million flats in multi-family buildings in the period of the biggest development of this technology. Currently, prefabricated concrete technology is becoming more and more important as a modern architectural material and it is the most-often used method of constructing residential buildings. Due to the new possibilities of using it, there has been a significant change in the way of thinking and shaping space, regarding it as a creation of flexi- 
stosowanych do różnych odbiorców i rosnących oczekiwań społecznych. Istnieje wiele możliwości jakie tkwią w obecnie produkowanych prefabrykowanych komponentach oraz zalet ekonomicznych i technologicznych. Zgodnie z rozwojem współczesnej architektury mieszkaniowej jesteśmy na drodze do stworzenia i przyjęcia nowych standardów również przy zastosowaniu prefabrykacji modularnej, typowych i powtarzalnych rozwiązaniach przestrzennych.

Celem artykułu jest spojrzenie na historie rozwoju prefabrykacji w Polsce z uwzględnieniem momentów zwrotnych, które w znaczny sposób wpłynęły na zmianę myślenia o tej technologii oraz przyspieszyły wzrost produkcji mieszkań i budynków mieszkalnych. Jaka była w przeszłości i jest obecnie rola prefabrykacji w kreacji architektury mieszkaniowej? Celem pracy nie jest rozstrzygnięcie o ilości pozytywów lub negatywów lecz podkreślenie potencjału jaki tkwi technologii prefabrykacji zarówno odnośnie jej obecnego rozwoju i przyszłej dominacji na rynku budowlanym jak i możliwości prowadzenia rewitalizacji w starych obiektach i przestrzeniach mieszkaniowych. W pewnym sensie potrzebne jest odbarwienie niechlubnej przeszłości i nowe spojrzenie na zastosowanie prefabrykatów w budownictwie przy racjonalnym wykorzystanie zyskanych doświadczeń wytwórczych i projektowych. Jak dalece prefabrykacja poprzez rozwój technologii, wartość historyczną i wyrazistość form budowlanych wpisała się w kształt architektury współczesnej?

\section{Początki prefabrykacji w Polsce - czas eksperymentu i rozwoju technologii}

Idea prefabrykacji rozwinęła się w ubiegłym stuleciu początkowo w Europie zachodniej, we Francji, Szwecji i Finlandii docierając również do Polski jako technologia częściowo zakupiona od wschodnich sąsiadów i częściowo opracowana na bazie zachodnich rozwiązań ${ }^{1}$ Za początki prefabrykacji w Polsce można jednak uznać stosowanie eksperymentalnych i częściowych metod wznoszenia obiektów. Już w połowie lat 50-tych wykorzystywano wielkowymiarowe prefabrykaty żużlobetonowe w wielorodzinnych budynkach mieszkalnych w Nowej Hucie (Wierzbicki,1999, s.12). Prefabrykaty były również stosowane od roku 1947 w podczas budowy warszawskiego osiedla TOR na Kole. Należały do nich bloki ścienne, ściany zewnętrzne trójwarstwowe i elementy ścianek działowych oraz pustaki stropowe dla systemu DMS, produkowane na miejscu budowy na tzw. poligonie prefabrykacji polowej (Syrkus 1976, s.347-352). Również od roku 1947 w trakcie budowy osiedla Muranów wykorzystywano pustaki gruzowe oraz prefabrykowane elementy konstrukcyjne: belki gruzowe, naproża, oraz obramienia okienne, krawężniki i gzymsy (Lachert, 1949, s.129-137). Po tym okresie własnych doświadczeń nad prefabrykacją, wracano często do wznoszenia budynków w cegły, i jak uznają teoretycy architektury, nastąpił wówczas regres w rozwoju nowych technologii wykonawstwa i zahamowanie prac nad nowoczesnymi konstrukcjami obiektów mieszkalnych.

Końcówka lat sześćdziesiątych dała początek technologii wielkoblokowej tzw. cegły żerańskiej a także budowie ble solutions adjusted to different recipients and growing social expectations. There is significant potential in currently produced prefabricated components and their economic and technological benefits. In accordance with the development of modern residential architecture, we are on the path to create and adopt new standards also by applying modular prefabrication, typical and repetitive spatial solutions.

The purpose of this paper is to look at the history of prefabrication development in Poland and present major breakthroughs, which significantly influenced changes in thinking about this technology. They also stimulated an increase in the construction of flats and residential buildings. What was the role of prefabrication in the creation of residential architecture in the past and what is it in the present? The purpose of this paper is not to determine the amount of positives or negatives but to highlight the potential of prefabricated technology in terms of its current development and future domination on the construction market, but also the possibilities of revitalising old buildings and residential spaces. In a sense, it is necessary to put the disgraceful past behind and take a new look at using prefabricated elements in the construction industry together with the rational use of experience related to design. To what extent has prefabrication been incorporated into the shape of contemporary architecture by the development of technology, historical value and clarity of building forms?

\section{The beginnings of prefabrication in Poland-a time} of experimentation and technological development The idea of prefabrication developed in the previous century, initially in Western Europe, in France, Sweden and Finland. It also came to Poland as a type of technology partially purchased from eastern neighbours and partially created on the basis of western solutions. ${ }^{1}$ Using experimental and partial methods of constructing buildings is regarded as the beginning of prefabrication in Poland. In the middle of the 1950s, prefabricated large-size slag-concrete blocks were used in multi-family residential buildings in Nowa Huta. (Wierzbicki, 1999, p. 12) Prefabricated components were also used from 1947 onwards during the construction of the TOR residential estate in the Koło area of Warsaw. They included wall blocks, three-layer outer walls, parts of partition walls and ceiling blocks used for the DMS system, which were produced on construction sites, via so-called on-site prefabrication manufacturing (Syrkus, 1976, p. 347352) After 1947, during the construction of the Muranów residential estate, precast concrete blocks and prefabricated construction elements were used, such as hard-core joists, lintels, window frames, curbs and cornices. (Lachert, 1949, p. 129-137). After a period of gaining experience with prefabrication, brick buildings were often constructed and, according to theorists of architecture, there was a regress in the development of new construction technologies and a hampering of work on modern structural systems for residential buildings. 

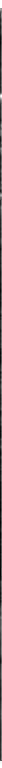

II. 1. Osiedle prototypów/autor zdjęcia Anita Orchowska / A prototype residential estate/author of photos Anita Orchowska II. 2. Osiedle prototypów/autor zdjęcia Anita Orchowska / A prototype residential estate/author of photos Anita Orchowska

pierwszego budynku wielkopłytowego w systemie PBU Jelonki. Poligonem doświadczalnym stała się budowa na warszawskim Służewcu osiedla prototypów ${ }^{2}$, w latach 1961-63, składającego się z prawie dwudziestu różnorodnych budynków wykonanych w technologii wielkiej płyty. Każdy z budynków był technologicznie różny i eksperymentalny, w jednym egzemplarzu, od niskich trzykondygnacyjnych i czterokondygnacyjny obiektów do siedmio- i dziewięciopiętrowych wieloklatkowych bloków. Różnorodność jaką wprowadzono miała posłużyć opracowaniu najlepszej, jednolitej konstrukcji, tak aby budynki mogły powstawać szybko i oszczędnie ${ }^{3}$. Największa liczba obiektów zbudowana została w systemie WUF-T, ale różniły się między sobą szczegółami, parterem handlowym lub mieszkalnym czy odwróceniem układu mieszkań. Przestrzennie prezentowały całkowitą odrębność. Większość realizacji pozostała prototypami, tylko dziesięciopiętrowe budynki z wielkiej płyty udało się sekwencyjnie realizować $w$ innych częściach Warszawy.

Z końcem lat 60-tych w wielu większych miastach polskich zaczęto stosować systemy regionalne budownictwa uprzemysłowionego. Istniało wiele lokalnych odmian, które w tym czasie się rozpowszechniły, a których autorami byli nasi rodzimi inżynierowie i konstruktorzy. Systemy lokalne takie jak WWP (Wrocław), Dąbrowa (Łódź), Winogrady (Poznań), Domino (Kraków), "J" (Warszawa), operowały zestawami gotowych budynków typowych. Powstające systemy centralne budownictwa wielkopłytowe jak choćby OWT-67, WUF-T oferowały ograniczone zestawy elementów, prefabrykatów w ramach typowych segmentów i budynków. Produkcja większości systemów regionalnych i centralnych odbywała się w wytwórniach poligonowych. W zorganizowanym w roku 1967 przez Ministerstwo Budownictwa i Przemysłu Materiałów Budowlanych konkursie na projekt otwartego systemu budownictwa wielkopłytowego
The late 1960s marked the beginning of large-panel technology, made of so called Żerańska brick, and also the first building to feature large-panel construction in the PBU system-Jelonki-was erected. The construction of a prototype residential estate ${ }^{2}$ in Warsaw, in the Służewiec area between 1961-1963, became a testing ground and consisted of almost twenty various buildings erected in large-panel technology. Each building was technologically different, experimental and in only one version. They ranged from low three- and four-storey buildings to sevenor even nine-storey blocks of flats with multiple stairwells. Introducing such a variety was supposed to help in identifying the best homogenous construction system in order to build quickly and cost-efficiently. ${ }^{3}$ The highest number of buildings was erected in the WUF-T system, but they differed in details, had either commercial or residential ground floors and they also had reversed flat layouts. They were fully spatially distinct. Most of the projects were just prototypes and only ten-storey large-panel tower blocks were subsequently erected in different parts of Warsaw. In the late 1960s, regional systems of industrialised structural systems were used in many Polish cities. There were many local types, which became widespread at that time and their authors were Polish engineers. The local systems such as WWP (Wrocław), Dąbrowa (Łódź), Winogrady (Poznań), Domino (Krakow), ' $J$ '(Warsaw) operated with finished sets of typical buildings. The central systems of a large-panel construction such as OWT-67 or WUF-T offered limited sets of elements, prefabricated components within typical dimensions and structures.

The production of the majority of regional and central systems took place in on-site manufactures. In 1967, there was a competition for the design of a large- 


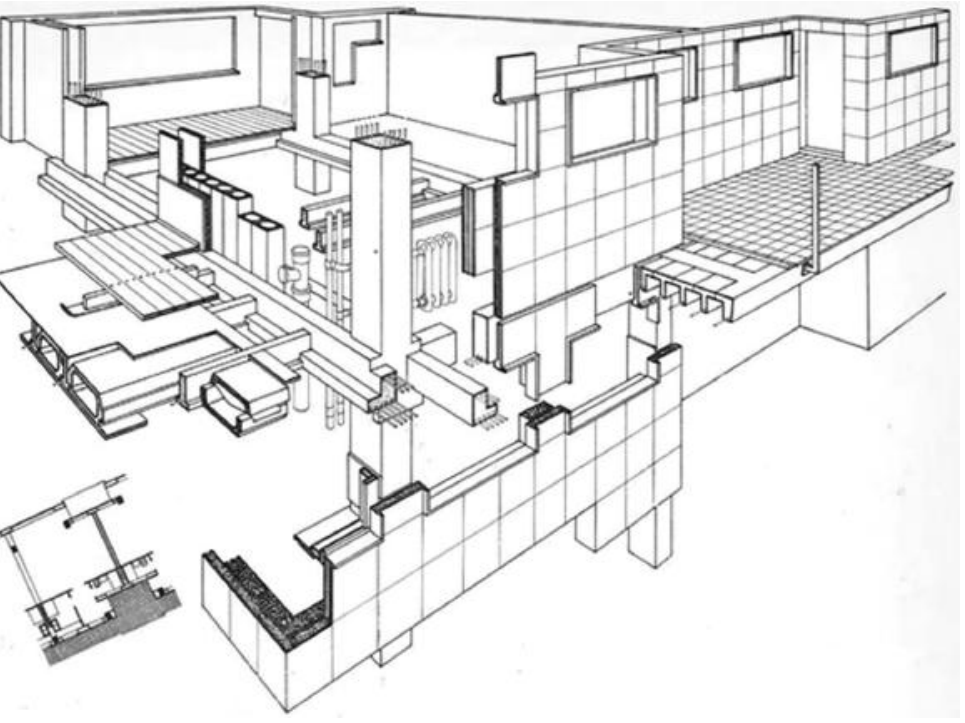

zwyciężył system „szczeciński" oraz W-70. Oba operowały katalogami typoszeregów prefabrykatów $i$ typowymi złączami, co pozwalało wprowadzać do projektów mieszkań i budynków różnorodność funkcjonalną (Wierzbicki, 1999, s. 12).

Z powodu presji społecznej w kwestii intensyfikacji produkcji uprzemysłowionej i na skutek decyzji politycznych, zaczęły powstawać Fabryki Domów. Pierwsza taka fabryka zaistniała w Jastrzębiu Zdroju w roku 1969. Zastosowano w niej sprowadzoną z NRD linię produkcyjną. W latach siedemdziesiątych wytwornie prefabrykatów zdominowały rynek mieszkaniowy ${ }^{4}$, a do roku 1980 w całej Polsce funkcjonowało 150 takich fabryk. Likwidacja wytwórni poligonowych i przełożenie ciężaru produkcji na fabryki prefabrykatów stwarzała duże możliwości rozwoju budownictwa mieszkaniowego. Wiele systemów prefabrykowanych rozpowszechniło się na cały kraj. Dla przykładu technologia W-70, z lokalnego systemu konstrukcyjno - montażowego stała się systemem ogólnopolskim powszechnie stosowanym ${ }^{5}$. Stało się to głównie dzięki możliwości dostosowania wielkości budynku oraz ilości kondygnacji do konkretnych uwarunkowań i zapotrzebowania, przy użyciu gotowych komponentów. Poza systemami otwartymi realizowane były projekty typowe, według systemów w zamkniętych, bez możliwości wprowadzenia zmian, (PBU, WUF-T, WWP) i częściowo zamkniętych (np. OWT), gdzie możliwe były zmiany w układach konstrukcyjnych i wysokościach budynków od 5-ciu do 11-stu kondygnacji. Poza wielkopłytowymi równolegle operowano systemami wielkoblokowymi , do najpopularniejszych należała cegła żerańska, ale także stosowano konstrukcje szkieletowe w postaci ramy typu $\mathrm{H}$, system $\mathrm{T}$ czy SBO. Warto wspomnieć, że w Polsce po raz pierwszy zastosowano prefabrykowaną konstrukcję szkieletową w postaci ramy w kształcie litery H już w roku 1955 w Łodzi w czasie budowy 11-kondygnacyjnej biblioteki uniwersyteckiej ${ }^{6}$. Typ ramowy został także wykorzystany w szkielecie serii budynków na warszawskim Muranowie (Lewicki, 1964, s. 60-61). Był to system, który zyskał popularność ze względu na brak
II. 3. Prefabrykacja-osiedla TOR na Kole/źródło: Syrkus H., Ku idei osidla społecznego 1925-1975, Państwowe Wydawnictwo Naukowe, Warszawa 1976, s. 347 / Prefabrication-TOR residential estate in Koło/source: Syrkus H., 'Towards the Idea of the Social Housing Estate 1925-1975', Państwowe Wydawnictwo Naukowe, Warszawa 1976, pp. 347

panel construction system organised by the Ministry of Construction and Building Materials Industry, which was won by the 'szczeciński system' and the W-70 system. Both systems operated with prefabricated series catalogues and typical joints, which allowed to introduce a functional variety into flat and residential building designs. (Wierzbicki, 1999, p. 12).

Due to social pressure triggered by the intensification of industrialised production and political decisions, House Factories began to operate. The first one appeared in Jastrzębie Zdrój in 1969. A production line brought from the GDR was used there. In the 1970s, the prefabricated production plants dominated the housing market, ${ }^{4}$ and there were 150 of such factories by 1980 across Poland. The shutting down of on-site manufactures and shifting the burden of production to prefabricated component factories created opportunities for the development of the housing construction industry. Many prefabrication systems were popular across the country. One example is the W-70 technology, which began as a local construction and assembly system and became widely used. ${ }^{5}$ This happened because of the possibilities of adjusting the size of a building and the number of floors to specific conditions and needs by using finished components. Apart from open systems, which were used to develop standardised designs, there were also closed ones, without the possibility of introducing any changes (PBU, WUF-T, WWP) and partially closed (for example, OWT) with possible modifications in construction systems and the height of the buildings from five to eleven floors. Large-panel systems were employed in parallel with large-block systems. The most popular was Żerańska brick but skeletal structures in the form of the $\mathrm{H}$-frame, the T-system or SBO were also used. It is worth mentioning that, in Poland, $\mathrm{H}$-shaped prefabricated skeletal structural systems were first used already in 1955 in Łódź, during the construction of an eleven-storey university library. ${ }^{6}$ This type was also used in the structure of the series of the buildings in 
występowania ścian nośnych co dawało możliwość elastycznej aranżacji przestrzeni wnętrz mieszkalnych.

Praca konstruktorów i projektantów nad udoskonaleniem technologii prefabrykowanych spowodowała, że wiele systemów doczekało się swoich kolejnych odmian (np. WUFT/67 na WUFT/72, OW-T na OWT/75 lub W-70 na Wk-70 ). W latach 1970 do 1989 funkcjonowały na rynku w sumie 24 podstawowe i zmodyfikowane systemy budownictwa wielkopłytowego.

Fabryki domów powstawały w miejscach, gdzie planowano budowę miast i osiedli praktycznie od podstaw, przeważnie jednak w taki sposób, aby dowóz prefabrykatów był opłacalny a materiał mógł być bezpośrednio dostarczany na miejsce budowy. Dla przykładu wspomniana wcześniej pierwsza krajowa fabryka w Jastrzębiu Zdroju (1969) i kolejna w Bziu Zameckim (1969) powstały dzięki decyzjom politycznych i miały służyć przyrostowi mieszkań dla pracowników kopalń. Fabryka FADOM $w$ całości więc podlegała przemysłowi górniczemu, a budynki powstawały przeważnie na Górnym Śląsku. Wkrótce stworzono sąsiednie Fadom w Żorach (1970) i Fabud w Michałowicach. Linia produkcyjna do tych wytwórni była zakupiona z NRD a pracownicy wyjeżdżali regularnie na szkolenia związane z technologią montażu urządzeń i procesem produkcyjnym, ale także wykonywali produkcję pod nadzorem szkoleniowców z Niemiec. Ogólna liczba pracowników tych fabryk liczyła ponad tysiąc osób, a sam obiekt składał się z kilku hal. Schemat produkcji był wszędzie podobny, począwszy od prac przygotowawczych potrzebna była zbrojownia, kolejno w poszczególnych halach produkowano płyty stropowe, dachy, ściany wewnętrzne i zewnętrzne. Taśmociągami dostarczano kruszywo i ustalano mieszankę do produkcji płyt, które z kolei powstawały w żeliwnych formach, gdzie zbrojenie łączono z betonem. Proces wiązania betonu trwał osiem godzin, a do form podłączano gorącą parę ,aby go przyśpieszyć. Podejmowane próby skracania czasu lub podnoszenia temperatury kończyły się niepowodzeniem i nieodwracanymi uszkodzeniami materiału lub odchyłkami wymiarowymi płyt ${ }^{7}$. Produkcja domów była zorganizowanych i olbrzymim przedsięwzięciem, a wytwórczość w fabrykach nacechowana olbrzymią wydajnością ${ }^{8}$ ukierunkowaną na liczbę mieszkań, z pominięciem jakość prefabrykatów. Takie podejście przyczyniało się powszechnie do dezorganizacji proces montażu i nie wróżyło przyszłości tej technologii.

\section{Koniec epoki uprzemysłowienia budownictwa}

Upadek budownictwa wielkopłytowego nastapił latach 90-tych kiedy pozamykano linie produkcyjne, wytwórnie prefabrykatów, gdyż stały się nieopłacalne. Niska jakość wytwarzanych elementów i błędy technologiczne ale przede wszystkim większe społeczne oczekiwania spowodowały, że nie miały szans w rywalizacji z nowymi zróżnicowanymi i bardziej ekonomicznymi technologiami wznoszenia budynków. Duże spółdzielnie mieszkaniowe zostały wyeliminowane z rynku mieszkaniowego na korzyść budownictwa prywatnego i działalności deweloperskiej. W tym samym czasie prywatne firmy pro-
Muranów district, (Lewicki, 1964, pp. 60-61) in Warsaw. It was a system that gained popularity as it did not include any partition walls. It enabled the flexible arrangement of flat interiors.

The work of structural engineers and designers on technology improvement caused many systems to have their further modifications (for example, WUFT/67 was changed into WUFT/72, OW-T into OWT/75 or W-70 into Wk-70). From 1970 until 1989 there were twenty-four basic and modified large- panel construction systems functioning on the market. House factories were opened in places where cities and residential estates were planned to be built from the bottom up, mostly in such a way as to make the delivery of the prefabricated elements cost-effective and so that the material could be directly delivered to construction sites. For example, the first factory in the country in Jastrzębie Zdrój (1969), which was mentioned before, and another one in Bzie Zameckie (1969) were opened thanks to political decisions and were supposed to increase the number of flats for mine workers. The FADOM factory was completely dominated by the mining sector and the buildings were erected mostly in the area of Upper Silesia. Soon, other neighbouring plants such as Fadom in Żory (1970) and Fabud in Michałowice were opened as well. Production lines in these plants were bought from the GDR and workers regularly took part in the training courses there, which covered assembly technology and production process. They also performed production under the supervision of instructors from Germany.

The total number of workers in these production plants amounted to over a thousand and the buildings themselves consisted of several floors. The pattern of production was similar everywhere, the reinforcement site was essential for preparatory works, consequently, in other rooms floor slabs, roofs, exterior and interior walls were manufactured. Aggregate was delivered by conveyors and the mixture was prepared for production of the slabs, which were made in cast-iron forms, where the reinforcing steel was combined with concrete. The process of concrete binding lasted eight hours and hot steam was supplied to the forms to make this process faster. Attempts to shorten the time of production or increase the temperature ended in failures, irreversible damages of the material or dimensional deviations of the slabs. ${ }^{7}$ The production of houses was an enormous and well-organised undertaking and it was immensely efficient ${ }^{8}$ as it focused on the number of flats, ignoring the quality of the prefabricated components. This attitude frequently contributed to disorganisation of the assembly process and it did not bode well for the future of this technology.

\section{The end of the construction industrialisation era}

The fall of the large-panel construction system took place in the 1990s, when the production lines were shut down and the plants of the prefabricated components became non-profitable. The low quality of 
dukujące materiały budowlane musiały podnieść swoją wydajność i jakość produktów, aby zdominować zakłady państwowe. W dalszym etapie ewolucyjnych zmian na rynku budowlanym rozpoczęła się ekspansja firm zagranicznych do Polski promujących nowoczesne materiały. Był to dodatkowy impuls do odejścia od przestarzałej technologii prefabrykacji betonowej na rzecz innych technologii jak choćby monolitycznej ${ }^{9}$, która pozwalała na nieskrępowane kształtowanie formy i swobodę w budowie funkcji obiektów.

Z punktu widzenia rozwoju budownictwa ukierunkowana prefabrykacja była rozwiązaniem rozsądnym i potrzebnym ze względu na konieczność zmniejszenie powszechnego głodu mieszkaniowego i na niską jakość ówczesnego budownictwa. Fabryki domów wykorzystywały niewielki procent swoich produkcyjnych możliwości, pojawiające się odchyłki prefabrykatów dezorganizowały montaż, a jakość budynków mieszkalnych pogarszała się. Najczęstszymi wadami prefabrykatów było przekraczanie dopuszczalnych odchyłek wymiarowych $w$ około $30 \%$ prefabrykatów oraz uszkodzenia i tzw. niedoróbki (Basista, 2001, s.85). Niestety wywołało to wieloletnie konsekwencje prowadzące do niekończących się remontów elewacji, likwidacji uszkodzeń wewnętrznych i nieszczelności oraz koniecznych dociepleń. W latach osiemdziesiątych ubiegłego stulecia powszechnie prowadzono termomodernizacje budynków, której celem było pomniejszenie kosztów eksploatacji i kompleksowe docieplanie przegród zewnętrznych oraz modernizacja instalacji wewnętrznych. Priorytetem okazało się likwidacja przede wszystkim mankamentów the elements and technological flaws, but most of all, greater social expectations made them unable to compete with new, diversified and more economical technologies of erecting buildings. Big housing cooperatives were eliminated from the housing market in favour of the commercial construction sector and the activities of the real estate developers. At the same time, private companies producing building materials had to increase their efficiency and quality of the products in order to supersede state factories. In a further evolutionary stage there was an expansion of foreign companies promoting modern materials on the housing market in Poland. It was an additional incentive to reject the outdated technology of concrete prefabrication in favour of other technologies such as the monolithic one, ${ }^{9}$ which allowed for unconstrained creation of forms and freedom in function design.

From the perspective of the development of the construction industry, targeted prefabrication was a sensible and necessary solution, because of the necessity to decrease common shortages of flats and low quality of construction at that time. House factories used just a small percentage of their potential output, the deviations of prefabricated components disorganised the assembly and the quality of residential buildings was getting worse. Exceeding the permissible deviations on sizes in about $30 \%$ of prefabricated components, damage or flaws (Basista, 2001, p. 85) were the most common defects in prefabricated parts. Unfortunately, it caused long-

II. 4. Prefabrykowane detale - osiedle Muranów/ źródło: Lachert B., “Muranów - dzielnica mieszkaniowa” Architektura 1949 nr 5 / Prefabricated details - Muranów residential estate/source: Lachert B., 'Muranów -the Residential District', Architecture 1949 no. 5

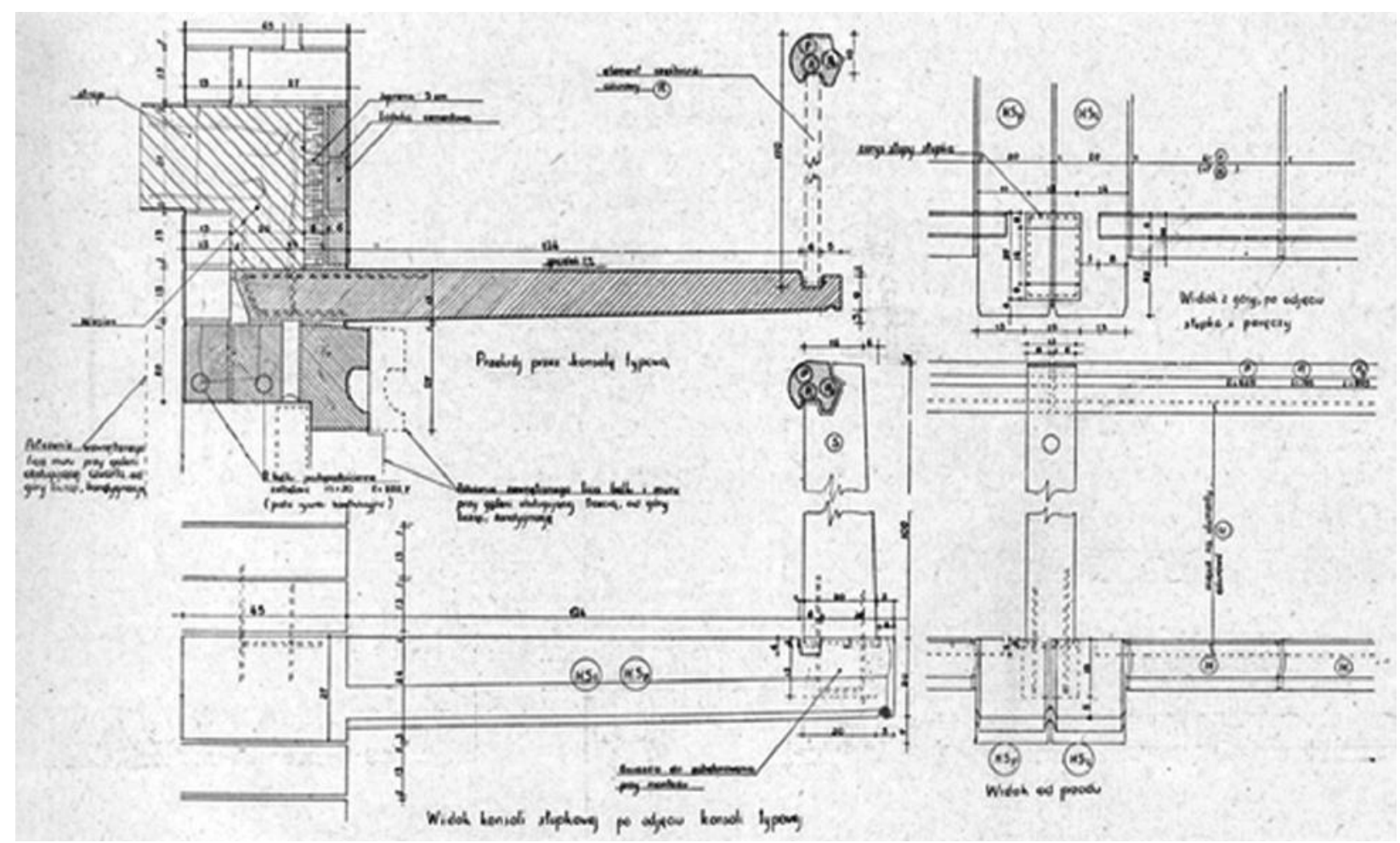


ścian a w tym likwidację mostków termicznych oraz wymiana okien. Ustawa w roku 1998 o wspieraniu przedsięwzięć termomodernizacyjnych okazała się niewystarczającym narzędziem do właściwe przeprowadzonej modernizacji. Dopiero późniejsza z roku 2009 Ustawa o wspieraniu termomodernizacji i remontów regulowała procedury remontowe i narzędziem do eliminacji podstawowych wad i usterek technicznych budynków (Orchowska, 2018, s. 43).

Obecnie za największe wady tamtych osiedli uważa się unifikacje budownictwa i monotonię podobieństw całych osiedli mieszkaniowych oraz szerzenie się negatywnych zjawisk społecznych. Największe znaczenia jednak dla kształtu architektury mieszkaniowej poza wadami konstrukcyjnym i technologicznymi było to, że wielka płyta spowodowała zwielokrotnienie wszelkich innych negatywnych cech budownictwa osiedlowego jego powtarzalność, anonimowość, brak indywidualizmu jako cech prawdziwej architektury oraz sztywny system konstrukcyjny nie dawał możliwości elastycznego myślenia o przestrzeni mieszkalnej (Basista, 2001, s. 85). Nie dała rady tego zmienić nawet skuteczna termomodernizacja, która ograniczała się jedynie do zmian kosmetycznych i kolorystycznych elewacji nie pozbawiając obiektów pierwotnego charakteru i ponad wymiarowej skali.

\section{Potencjał i wartości osiedli mieszkaniowych}

Prefabrykowane osiedla mieszkaniowe stanowią obecnie niedoszacowana wartość, po pierwsze ze względu na tereny jakimi dysponują, często śródmiejskie i doskonałe lokalizacyjnie oraz przestrzennie - w miejscach, gdzie nie udało się pierwotnych założeń urbanistycznych zmienić a wolną przestrzeń zabudować. W założeniach wiele osiedli dysponowało swobodą przestrzeni, zakomponowanymi zieleńcami i terenami otwartymi oferując mieszkańcom wartość zamienną, rekompensując w ten sposób małe i ciasne mieszkania oraz typowe bloki. Warunki higieniczne zabudowy zapewniały odpowiednie przewietrzanie, nasłonecznienie i zamierzony kontakt ze środowiskiem naturalnym. Niezaprzeczalna wartość historyczna związana jest z powstawaniem i kształtowaniem środowiska zamieszkania, zawierająca barwne historie życia całych społeczności i poszczególnych mieszkańców. Odmienność i różnorodność osiedli jaką można dostrzec zawarta jest w podobieństwie formy i kształtu zabudowy oraz specyficznym klimacie jednostek mieszkaniowych. Te właśnie elementy charakter terenu w otoczeniu budynków, rodzaj konstrukcji oraz możliwości techniczne obiektów są obecnie podstawą dyskusji nad przyszłością blokowisk.

Idea skutecznej rewitalizacji, bo o niej mowa, opiera się więc na utrzymaniu zasobów i prowadzeniu działań podnoszących wartość techniczną, estetyczną i funkcjonalną, ale także jest sposobem na zmiany w zakresie struktury samych budynków. Upoważnienie do działań rewitalizacyjnych dają sprecyzowane wartości i rozmaitość technologii prefabrykacji jaka tkwi obiektach mieszkaniowych. Każda z technologii to indywidualny sposób na działania naprawcze. Wspólna jest jednak przyszłościowa idea przebudowy bloków z zastosowaniem udogodnień funkcjonalnych i zmian w użytko- term consequences leading to never-ending renovations of façades, the elimination of interior damages and leakages or the necessity for thermal insulations. In the 1980s, building thermal retrofitting was widely being carried out. It served the purpose of decreasing maintenance costs, carrying out extended thermal insulations of building envelopes and modernising internal installations. Eliminating wall defects, including the removal of thermal bridges and replacement of window frames were the priorities. The Act of 1998 on supporting thermal refurbishment turned out to be insufficient in properly facilitating modernisation measures. The subsequent Act of 2009 on supporting thermal refurbishment and renovation works regulated renovation procedures and was the tool to eliminate basic faults and technical defects of the buildings. (Orchowska, 2018, p. 43).

The unification of the construction sector, monotony of similarities of entire residential estates and the spread of negative social phenomena are currently considered to be the biggest disadvantages of prefabricated housing estates. Apart from construction and technological defects, the use of large-panel systems, which caused the multiplication of other negative features of housing construction, was the most significant for the shape of residential architecture. Its repetitiveness, anonymity, lack of individuality, the qualities of the real architecture and rigid construction system did not give any possibility to think about housing space in a flexible way. (Basista, 2001, p. 85) Even effective thermal refurbishment did not manage to change it, as it was limited only to cosmetic changes and colourful façades, not eliminating the original character and oversized scale of buildings.

\section{The potential and value of housing estates}

At present, prefabricated housing estates have an underestimated value, mostly because of their premises. As they are often located in city cetnres, they are ideal in terms of location and space, where the original urban planning schemes failed to be changed and free space could not be built up. In the schemes many housing estates offered space, green squares and open areas giving the residents an interchangeable value, compensating in this way for small, cramped flats and ordinary blocks. The hygienic conditions of the developments were guaranteed by proper ventilation, sun exposure and intentional contact with the natural environment. Their undeniable historic value is connected with formation and shaping of the housing environment, including colourful life stories of the communities and individual tenants. Differences and varieties of the housing estates, which are noticeable, are included in the similarities of forms and shapes of the developments and specific climate of housing units. These elements, the character of the area surrounding the buildings, the type of structural systems and technical capabilities of the buildings currently serve as a basis for discussion on the future of housing projects.

The idea of effective revitalisation, which is being discussed here, is based on keeping the resources 


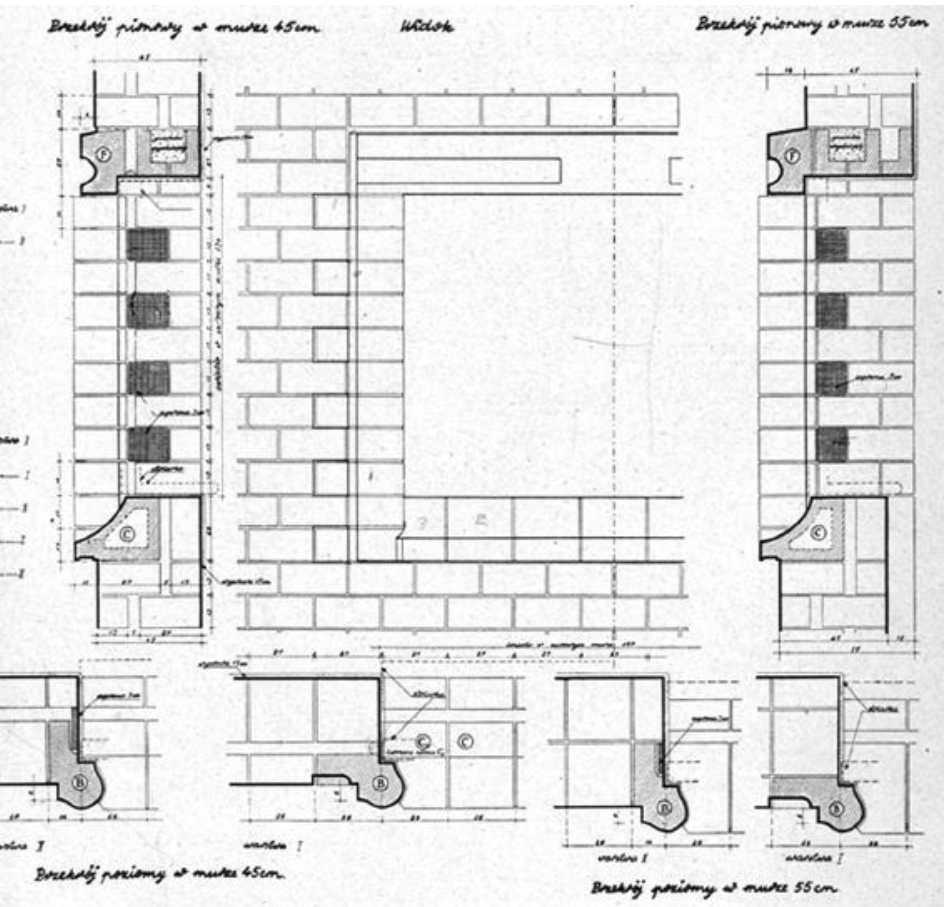

II. 5. Prefabrykowane detale - osiedle Muranów/źródło: Lachert B. "Muranów - dzielnica mieszkaniowa" Architektura 1949 nr 5 / Prefabricated details - Muranów residential estate/source: Lachert B., 'Muranów -the Residential District', Architecture 1949 no. 5

waniu przestrzeni, częściowych wyburzeń, obniżaniem kondygnacji, uzupełnień budynków nowymi fragmentami czy wreszcie re-użycie płyt betonowych powstałych z rozbiórki. Projekty pilotażowe z mniejszym czy większym powodzeniem jednak dalszym ciągu prowadzone są Europie w ramach modernizacji osiedli prefabrykowanych. Zmieniające się standardy mieszkaniowe a także potrzeby społeczne zmuszają projektantów do rozwiązań kreatywnych związanych z nowoczesnym podejściem do mieszkalnictwa. Z drugiej strony jest rzeczą jasną, że nie można trwale zmienić środowiska mieszkaniowego bez radykalnych zmian w nim samym. Wykorzystanie olbrzymiego potencjału lokalizacyjnego i strukturalnego budynków jest najważniejszym elementem procesu rewitalizacji terenów mieszkaniowych i jest zagadnieniem ważnym dla funkcjonowania osiedli w przyszłości.

Aby zapewnić długi okres użytkowania należy dostrzec zdolności adaptacyjne prefabrykowanych bloków do nowych potrzeb. Trwałość budynku określana jest więc mianem zdolności do jej przekonfigurowania, elastycznością i możliwościami przekształceń nie będącymi w sprzeczności z jej dotychczasowym użytkowaniem. Zabudowa może być więc inspiracją do działań modernizacyjnych związanych z bardziej odważnymi działaniami związanymi z przebudową bloków redukcja kondygnacji a nawet użyciem materiału rozbiórkowego. Temat re-użycia płyt prefabrykowanych był już przez autorkę niniejszego artykułu badany. Do najważniejszych zalet jakie tkwią w tego rodzaju systemowej przebudowie należą oszczędności na różnym poziomie inwestycji od terenowych po materiałowe, szybszy od tradycyjnego sposób realizacji inwestycji, wizualna zmiana charakteru zabudowy i kreacja atrakcyjnego środowiska mieszkanio- and enacting measures that improve technical, aesthetic and functional values, but also it is a method for introducing changes in terms of the buildings' structure. An authorisation for revitalisation activities gives clearly defined values and varieties of prefabrication technologies of housing buildings. Each technology stands for an individual method of reconstruction works. However, the future idea of reconstructing the blocks of flats is common. It involves the construction of functional facilities and changes in using space, partial demolitions, lowering storeys, the addition of new elements or finally reusing the concrete slabs from demolition works. Pilot projects involving modernisation of prefabricated housing estates are still carried out in Europe with varying success. Changes in housing standards as well as social needs force designers to introduce creative solutions connected with a modern approach to housing. On the other hand, it is clear that the housing environment cannot be permanently changed without any radical modifications. The most significant part of the revitalisation process of residential areas includes taking advantage of the enormous potential of sites and structures of the buildings and it is also an important issue for the future functioning of the housing estates.

In order to provide a long period of usage, it is essential to identify the adaptive reuse potential of prefabricated blocks of flats. The durability of a building is defined by its ability to be reconfigured, its flexibility and reconstruction potential, which are not in contradiction with its previous usage. Consequently, a housing development might be an inspiration for modernisation connected with more serious works such as remodelling blocks of flats, lowering the storeys or even the use of material reclaimed from demolition. The subject of re-using prefabricated slabs has already been researched by the author of this article. The most important benefits of this type of system reconstruction are the cost-effectiveness at different levels of the project, ranging from locations to materials, faster project completion in comparison to traditional projects, visual changes to a housing developments' character, the creation of attractive housing environments, of the possibility of leaving residents in a wellknown environment in accordance with their fondness and habits. Other merits include using the iarea for any works to improve its functioning and, finally, a considerable amount of the building material and possibilities of its use. (Orchowska, 2016, pp. 365-374) Knowledge about older technologies of prefabrication and methods of remedial works has potential and is an information resource, which allows to avoid performance, assembly and organisational errors both in the present and in the future.

Active ways of seeking the best previously used methods of prefabrication, by using more or less suitable technologies, attempts to create universal rules of erecting buildings still have a significant impact on the future of housing construction. Using more complex prefabrication systems, in which a bigger number of fixed elements was used, led to 
wego, możliwości pozostania mieszkańców w znanym sobie środowisku, zgodnie z zamiłowaniami i przyzwyczajeniami. Poza tym wykorzystanie zainwestowanego terenu do działań polepszających jego funkcjonowanie i wreszcie, duża ilość budulca i możliwości jego zastosowania (Orchowska, 2016, s. 365-374). Wiedza o starszych technologiach prefabrykacji i sposobach działań naprawczych stanowi potencjał i zasób informacji, który pozwala uniknąć błędów wykonawczych, montażowych i organizacyjnych obecnie i w przyszłości.

Czynne poszukiwanie najlepszych metod prefabrykacji w minionych okresach, poprzez stosowanie mniej lub bardziej poprawnych technologii, próby tworzenia uniwersalnych reguł wznoszenia obiektów mają w dalszym ciągłu wielki wpływ na przyszłość budownictwa mieszkaniowego. Wykorzystywanie bardziej skomplikowanych systemów prefabrykacji, w których stosowano większą ilość stałych elementów prowadziło do budowy bardziej urozmaiconych form architektonicznych, natomiast technologie uboższe, stosujące większe uproszczenia prowadziły do kreacji nieelastycznych rozwiązań przestrzennych i funkcjonalnych mieszkań oraz wprowadzały banalność estetyczną budynków. (Orchowska, 2018, s. 30)

\section{Nowa prefabrykacja}

Dzisiejszy rozwój technologii stawia na pierwszym planie, w zakresie typowych rozwiązań poza ekonomicznym, czynnik jakości i wytrzymałości poszczególnych elementów prefabrykowanych. Obecnie wyrazem postępu technologicznego jest zarówno proces uprzemysłowienia robót budowlanych jak i wytwarzanie odpowiedniej jakości różnorodnych prefabrykatów, w kompleksowym przedsięwzięciu budowy obiektów. Wytwarzanie prefabrykatów betonowych więc w wyspecjalizowanych zakładach ma na celu produkcję elementów odpowiedniej jakości, precyzyjnie wykonanych i powtarzalnych dla uzyskanie odpowiedniej wydajności produkcji oraz odpowiednio wytrzymałych. W tym przypadku koniczność prowadzenia rotacji form sprzyja podtrzymaniu wydajności zakładów produkcyjnych oraz dalszej dystrybucji do klienta. Poza wielkościowym kryterium podziału elementów prefabrykowanych istnieje przede wszystkim wiele rodzajów użytego betonu w zależności od technologii i przeznaczenia elementów. Do najczęściej stosowanych należą: betony o konsystencji plastyczno-ciekłej i samozagęszczalne, beton ze zbrojeniem rozproszonym (fibrobeton), z zawartością włókien szklanych, beton o konsystencji wilgotnej oraz beton architektoniczny ${ }^{10}$, ale także inne rzadsze mieszanki o szczególnych właściwościach np. beton wysokowartościowy, samoczyszczący lub transparentny. Dzięki odpowiednim modyfikacjom składu mieszanki betonowej można uzyskać przydatne właściwości tego materiału np. odwadniające, ciepłochronne czy dekoracyjne. Dla przykładu beton architektoniczny może spełniać nawet największe wymagania estetyczne architektów także pod względem faktury i barwienia powierzchni.

Produkcja prefabrykatów wymaga szczegółowego przygotowania. Można powiedzieć, że proces produkcji constructing more varied architectural forms, while poorer technologies that applied greater simplification led to creating inflexible spatial and functional flat solutions and introduced banal architectural aesthetics. (Orchowska, 2018, p. 30)

\section{New prefabrication}

The current development of technologies puts the quality and durability factor of specific prefabricated elements first in terms of typical solutions, except of economic ones. At present, the expression of technological progress includes both the process of the industrialisation of construction work and manufacturing prefabricated parts of proper quality in complex construction projects. Producing prefabricated concrete components in specialised plants has the purpose of manufacturing elements, which have an appropriate quality, are made in a precise way and are repetitive so as to achieve proper productivity and durability.

In this case, the necessity to carry out rotation of forms encourages to sustain productivity of manufacturing plants and further distribution to customers. Apart from the size criteria of dividing prefabricated elements, there are many types of concrete used depending on technology and purpose of elements. The most common include: concrete with a plastic and liquid consistency, self-composed concrete, reinforced concrete (fibre-reinforced concrete) with glass fibre content, earth-moist concrete and decorative concrete, ${ }^{10}$ but also other rare mixtures with specific characteristics, for example, high-performance, self-cleaning or transparent concrete. Thanks to appropriate modifications of ingredients of the concrete mixture, useful properties of this material may be obtained, i.e. dehumidifying, insulating or decorative. For instance, decorative concrete may fulfil the three essential aesthetic requirements of architects, also in terms of texture and surface colouring.

The production of prefabricated components requires detailed preparation. It can be said that the production process starts at the stage of designing a building and it makes up the biggest part of the formation process of an architectural project. Currently, there has been a significant shift towards longer time spent on creating a technological design of a building in proportion to the time of the delivery of prefabricated elements, much less on the construction of the building object itself. The technical documentation includes not only the modularity of wall and ceiling elements, but also the physical, chemical and visual parameters of concrete intended for a specific prefabricated element. That is why detailed technological drawings of the building must be prepared, involving close cooperation between architects and structural engineers. Technologically uncomplicated buildings do not require a dedicated system of prefabrication but they may be based on the guidelines presented in the catalogues of manufacturers. Thus, any problems connected with production or assem- 
zaczyna się na etapie projektowania obiektu i stanowi największa cześć procesu powstawania realizacji architektonicznej. Nastąpiło obecnie znaczne przesunięcie czasochłonności wytworzenia projektu technologicznego obiektu w stosunku do czasu realizacji prefabrykatów, a tym bardziej realizacji samego obiektu. Dokumentacja techniczna uwzględnia nie tylko modułowość elementów ściennych i stropowych ale ponadto parametry fizyczne, chemiczne i wizualne betonu przewidziane dla konkretnego prefabrykatu. Precyzyjne rysunki technologiczne obiektów muszą być wobec tego przygotowywane przy uwzględnieniu ścisłej współpracy konstruktora i architekta. Proste technologicznie obiekty nie potrzebują opracowania systemu prefabrykacji lecz mogą opierać się na podstawie wytycznych przedstawionych w katalogach producentów. Dzięki temu można uniknąć problemów związanych z produkcją i montażem prefabrykatów na budowie. Dobra jakość prefabrykatów można zapewnić dzięki wieloetapowej ich kontroli począwszy od prac przygotowawczych, produkcji aż po odbiór ${ }^{11}$ i dystrybucję gotowych elementów.

Wiele dziedzin budownictwa jest obecnie zdominowane przez prefabrykacje betonową. Również budownictwo mieszkaniowe stawia od nowa kroki w stronę powszechnego zastosowania prefabrykatów, o jakości odpowiadającej obecnym potrzebom. Wymierne korzyści nowej prefabrykacji występują na rożnych poziomach produkcji i użytkowania, a za jej pośrednictwem można wznosić obiekty uprzemysłowione całości lub łączyć je z innymi technologiami. Do zalet należą przede wszystkim szybkość wznoszenia obiektów, gdyż dominuje tu montaż, nad robotami mokrymi oraz duże uniezależnienie się od warunków pogodowych. Występująca możliwość optymalizacji jakości, zapotrzebowania materiałowego i energochłonności co pozwalana na wytwarzanie prefabrykatów precyzyjnych technologicznie. Nie pozostaje to bez znaczenie dla kształtowania bryły zgodnie z indywidualnym zapotrzebowaniem funkcjonalnym i estetyczny twórców architektury. Istotą usprawnienia nowej prefabrykacji jest również zapewnienie ciągłości i bazy doświadczeń wynikających z okresów minionych (np. stosowanie nowoczesnych i trwałych złączy), zapewnienie elastyczności i uniwersalności produktom powstającym w tej technologii.

\section{Wnioski}

Prefabrykacja wpłynęła w znaczy sposób na kształt architektury mieszkaniowej XX wieku a jej znaczenie nadal nie słabnie. Zadaniem prefabrykacji w przeszłości było zaspokojenie niedoboru lokali mieszkalnych. Czas eksperymentu przeobraził się w burzliwy okres rozwój technologii, systemów budownictwa i ich odmian, a rolą prefabrykacji było kształtowanie podstawowych standardów mieszkaniowych. Poprzez masowość zjawiska czas ten ten stał się jednym z najbardziej wyrazistych okresów rozwoju budownictwa mieszkaniowego, budowy charakterystycznych do dzisiaj elementów i struktur funkcjonujących w przestrzeni miast. Pozostała w ten sposób spuścizna technologiczna do dzisiaj wzbudza szacunek i uznanie wśród konstruktorów. Pogląd ten bazuje na olbrzymiej ilością doświadczeń zyskanych bly of prefabricated components at the construction site may be avoided. Good quality of prefabricated parts might be provided by multi-stage supervision that starts with preparatory works, production and ends with delivery ${ }^{11}$ and distribution of the finished components.

Currently, many fields of construction are dominated by concrete prefabrication. Housing construction is again taking steps towards a wide use of prefabricated elements that have a quality that satisfies current needs. The tangible benefits of new prefabrication are noticeable at different levels of production and usage, and through it industrialised buildings may be erected in whole or they may be connected with other technologies. Benefits include the speed of constructing the buildings, as it is mainly based on assembly, not on wet works, and significant independence from weather conditions. The possibility of optimising the quality, material demand and energy consumption allows to produce prefabricated components, which are technologically accurate. It is significant for shaping a building in line with individual functional and aesthetic needs of architecture's designers. The key point of improving the new prefabrication is also providing continuity and a database of experience resulting from past periods (for example, using modern and durable joints), ensuring the flexibility and versatility of products made in this technology.

\section{Conclusions}

Prefabrication had a significant influence on the shape of the residential architecture of the twentieth century and its importance has not diminished. In the past, the purpose of prefabrication was to tackle housing shortages. A time of experimentation changed into a turbulent period of technological advancement, development of construction systems and their types and the role of prefabrication was to create basic housing standards. As it was a mass phenomenon, this time became one of the most distinct periods of housing development, of constructing characteristic elements and structures that continue to function in urban spaces. Thanks to this, a technological legacy has been left and it is respected and recognised among constructors. This viewpoint is based on an enormous amount of experience obtained first in on-site manufacturing plants, then in house factories, but also at construction sites, where building and technical issues of industrialisation of the construction industry were legalised with a good effect. Prefabrication, in this respect, started from a primitive manufacture and became an enormous technological achievement and is a potential source of further housing development in Poland. In that sense, this technology has fulfilled its purpose, and what is more important, the period of changes and development has not seen its definitive end. Space and form do not serve a single purpose of increasing the number of negative opinions here. However, it is a way towards flexible and 
w wytwórniach poligonowych, następnie w późniejszych fabrykach domów oraz na miejscu budowy, gdzie z należytym skutkiem legalizowano konstrukcyjne i techniczne kwestie uprzemysłowienia budownictwa. Prefabrykacja w takim zakresie od prymitywnej manufaktury stała się olbrzymim osiągnięciem technologicznym i jest potencjalnym źródłem dalszego rozwoju mieszkalnictwa w Polsce. W tym znaczeniu ta technologia spełniła swoją rolę, a co ważne okres przemian i rozwoju nie został ostatecznie zamknięty. Przestrzeń i forma nie służy tu jedynie mnożeniu negatywnych ocen lecz jest drogą dojścia do elastycznych i funkcjonalnych przeobrażeń, które mają swoich zwolenników, także obecnie wśród architektów i konstruktorów.

Kontynuowany dzisiaj stopniowy powrót do technologii prefabrykacji ma na celu wznoszenie budynków w całkowicie nowej odsłonie, a sam proces produkcji elementów przeszedł przeistoczenie. Rolą nowej prefabrykacji jest przede wszystkim eliminacja błędów technologicznych i niedociągnięć jakościowych oraz produkcja szerokiej gamy różnorodnych komponentów do zastosowania w budownictwie. Ciężar realizacji w dużej mierze zależy od etapu projektowego i przygotowania technologii, mniej od produkcji czy wznoszenia struktury. Obecnie o standardach budynków decydują możliwości finansowe inwestora, a typizacja rozwiązań jest atutem w grze o intratność przedsięwzięć mieszkaniowych. Prefabrykacja modularna jest dla architektury współczesnej znacznym wyzwaniem ze względu na balast przeszłych doświadczeń i jest też oczywistym zaprzeczeniem stosowania zaniżonych standardów przestrzennych i unifikacji rozwiązań wizualnych. Z jednej strony elastyczność i różnorodność projektowanych elementów, z drugiej strony lepsze technologicznie prefabrykaty, w znaczny sposób pozwalają dostosować swoją typizację do współczesnych wymagań użytkowych i estetycznych architektury mieszkaniowej.

\section{PRZYPISY}

1 Trudno mówić tu o jednej technologii. Było ich wiele, niektóre systemy były opracowywane od nowa w krajowych burach projektowych, inne w oparciu o zakupione w ZSRR linie technologiczne, a jeszcze inne na bazie rozwiązań stosownych w NRD.

2 Osiedle prototypów zlokalizowane zostało w rejonie ulic: Rzymowskiego, Orzyckiej, Modzelewskiego i Lotników.

https://magazynkontakt.pl/osiedle-prototypow/ (odsłona z dnia 25.04.2020)

${ }^{4}$ https://culture.pl/pl/artykul/skad-sie-wziely-bloki (odsłona 26.04.2020)

5 Pierwsze tego typu budynki powstały w Radomiu w roku 1972.

${ }^{6}$ Prefabrykaty wykonywane były na placu budowy.

$7 \mathrm{http}: / /$ jaspedia.eu/wpis/73/fabryka-domow-fadom.html (odsłona z dnia 8.05.2020)

${ }^{8}$ Fabryki w Jastrzębiu i Żorach produkowały 2000 mieszkań rocznie.

9https://episcope.eu/fileadmin/tabula/public/docs/brochure/PL_TABULA TypologyBrochure_NAPE.pdf , s.9-10,15-17

https://webcache.googleusercontent.com/search?q=cache:fXZxRmX L2PMJ:https://www.gorazdze.pl/pl/system/files_force/assets/document/ e5_beton_w_prefabrykacji_www.pdf\%3Fdownload\%3D1+\&cd $=1 \& \mathrm{hl}=\mathrm{pl}$ $\varepsilon_{c \bar{t}}=\mathrm{clnk \overline {g } g |}=$ pl\&client $=$ firefox-b-d (odsłona $z$ dnia 22.04.2020)

https://www.muratorplus.pl/technika/konstrukcje/materialy-do-produkcji-prefabrykatow-betonowych-aa-Ge9V-oSqx-Gzpd.html (odsłona z dnia 22.04.2020)

\section{LITERATURA}

[1] Basista A., Betonowe dziedzictwo, Wydawnictwo Naukowe PWN 2001, s. 85

[2] Lachert B., "Muranów - dzielnica mieszkaniowa" Architektura 1949 nr 5, s.129-137,1949. functional transformations, which today have their supporters also among architects and structural engineers.

A gradual return of prefabrication technology, which is seeing its present-day continuation, has the purpose of erecting buildings in a totally new way and an entirely new process of component production has emerged. The role of new prefabrication is, above all, to eliminate technological mistakes, quality defects and produce a wide range of various elements to be used in the construction industry. The difficulty of construction mostly depends on the design stage and the preparation of technology, less on production or erecting a structure. Currently, the financial possibilities of developers influence the standards of buildings and standardisation of solutions is an advantage in terms of the profitability of residential projects. Modular prefabrication is a considerable challenge for contemporary architecture due to the burden of past experiences. It is also a clear negation of applying understated spatial standards and standardising visual solutions. On the one hand, there is a flexibility and variety of elements that are designed, while on the other, prefabricated components, which are technologically better, allow the adjustment of standardisation to contemporary functional and aesthetic requirements of residential architecture.

\section{ENDNOTES}

1 It is hard to talk about only one technology. There were many of them, some systems were created from the beginning in nationa design studios, others were based on technological lines purchased form the USSR and some others were based on the solutions applied in the GDR.

2 The residential housing estate of prototypes located in the area of the Rzymowskiego, Orzyckiej, Modzelewskiego and Lotników streets.

3 https://magazynkontakt.pl/osiedle-prototypow/ (accessed on: 25.04.2020)

4 https://culture.pl/pl/artykul/skad-sie-wziely-bloki (accessed on: 26.04.2020)

${ }^{5}$ The first buildings of this type were constructed in Radom in 1972. ${ }^{6}$ Prefabricated components were manufactured on the construction site.

7 http://jaspedia.eu/wpis/73/fabryka-domow-fadom.html (accessed on: 8.05.2020)

${ }^{8}$ Factories in Jastrzębie and Żory produced 2000 flats per year. ${ }_{9}$ https://episcope.eu/fileadmin/tabula/public/docs/brochure/PL TABULA TypologyBrochure NAPE.pdf, pp.9-10,15-17

https://webcache.googleusercontent.com/search?q=cache:fX ZxRmXL2PMJ:https://www.gorazdze.pl/pl/system/files_force/as-

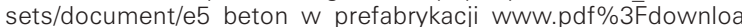

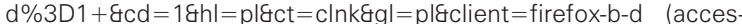
sed on: 22.04.2020)

https://www.muratorplus.pl/technika/konstrukcje/materialy-do-produkcji-prefabrykatow-betonowych-aa-Ge9V-oSqx-Gzpd.html (accessed on: 22.04.2020)

\section{REFERENCES}

[1] Basista A., 'Concrete Heritage', Wydawnictwo Naukowe PWN 2001, p. 85

[2] Lachert B., 'Muranów -the Residential District', Architecture 1949 no. 5, pp. 129-137, 1949

[3] Lewicki B., 'Residential Buildings of Large-size Prefabricated Components', Construction-Art-Architecture, Wydawnictwo Arkady, Warszawa 1964, pp.10,11,60,61.

[4] Orchowska A., Technical and architectural problems in revitalization of prefabricated residential complexes, Czasopismo Inżynierii Lądowej, Środowiska i Architektury JCEEA 2018, b. 65 no. 4, pp. 39-48. [5] Orchowska A., Architectural solutions with application of re-used prefabricated slabs, Czasopismo Inżynierii Lądowej, Środowiska i Architektury, JCEEA, 2016, 63 (4/16), pp. 365-374 
3] Lewicki B., Budynki mieszkalne z prefabrykatów wielkowymiarowych, Budownictwo-Sztuka-Architektura, Wydawnictwo Arkady, Warszawa 1964, s.10,11, 60,61 .

[4] Orchowska A., Technical and architectural problems in revitalisation of prefabricated residential complexes, Czasopismo Inżynierii Ladowej, Srodowiska i Architektury JCEEA 2018, Z.65 nr 4, s.39-48.

[5] Orchowska A., Architektoniczne rozwiązania z zastosowaniem re-użycia płyt prefabrykowanych, Czasopismo Inżynierii Ladowej, Srodowiska i Architektury, JCEEA 2016, 63 (4/16) s. 365-374

[6] Orchowska A., Prefabrication - the expression of rationalism in architecture, [w:] Defining the architectural space : rationalistic or intuitive way to architecture, Vol. 7/ 2018, s.23-31.

[7] Syrkus H., Ku idei osidla społecznego 1925-1975, Państwowe Wydawnictwo Naukowe, Warszawa 1976, s.347-352.

[8] Wierzbicki S.M., Problemy modernizacji budynków wielkopłytowych, Możliwosci techniczne modernizacji budynków wielkopłytowych w Polsce na tle ich aktualnego stanu. Materiały konferencyjne, Instytut Techniki Budowlanej 1999, s. 12.

\section{INNE ŹRÓDŁA INFORMACJI}

[1] https://magazynkontakt.pl/osiedle-prototypow/ (odsłona z dnia 25.04.2020 [2] https://www.muratorplus.pl/technika/konstrukcje/materialy-do-produkcji-prefabrykatow-betonowych-aa-Ge9V-oSqx-Gzpd.html(odsłona z dnia 22.04.2020)

[3]https://webcache.googleusercontent.com/search?q=cache:fXZXRmXL2PM :https://www.gorazdze.pl/pl/system/files_force/assets/document/e5_beton_w

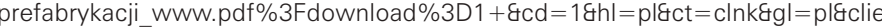
nt $=$ firefox-b-d (odsłona $z$ dnia 22.04.2020)

[4] https://culture.pl/pl/artykul/skad-sie-wziely-bloki (odsłona z dnia 26.04.2020).

[5] https://episcope.eu/fileadmin/tabula/public/docs/brochure/PL_TABULA_Typo-

ogyBrochure NAPE.pdf, s.9,10,15-17 (odsłona z dnia 29.04.2020)

[6] http://jaspeedia.eu/wpis/73/fabryka-domow-fadom.html (odsłona z dnia 8.05.2020)
6] Orchowska A., Prefabrication - the expression of rationalism in architecture, [in:] Defining the architectural space: rationalistic or intuitive way to architecture, vol. 7/ 2018, pp. 23-31.

77] Syrkus H. 'Towards the Idea of the Social Housing Estate 1925-1975', Państwowe Wydawnictwo Naukowe, Warszawa 1976, pp. 347-352

8] Wierzbicki S.M., Problems of modernization of large-pane buildings. Technical possibilities of modernizing large-panel buildings in Poland compared to their current state. Conference materials. Instytut Techniki Budowlanej 1999, p. 12.

\section{OTHER SOURCES OF INFORMATION}

[1] https://magazynkontakt.pl/osiedle-prototypow/ (accessed on: 25.04.2020

[2] https://www.muratorplus.pl/technika/konstrukcje/materialy-do-produkcji-prefabrykatow-betonowych-aa-Ge9V-oSqx-Gzpd.html (accessed on: 22.04.2020)

[3]https://webcache.googleusercontent.com/search?q $=c$ ache:fXZxRmXL2PMJ:https://www.gorazdze.pl/pl/system/ files force/assets/document/e5 beton w prefabrykacji www.pdf\%3Fdownload\%3D1+\&cd $=1 \& \overline{\mathrm{hl}}=\overline{\mathrm{p}} \mid \mathrm{qct}=\mathrm{clnk \& gl}=$ pldclient=firefox-b-d (accessed on: 22.04.2020)

[4] https://culture.pl/pl/artykul/skad-sie-wziely-bloki (accessed on: 26.04 .2020

[5] https://episcope.eu/fileadmin/tabula/public/docs/brochure/ PL_TABULA TypologyBrochure_NAPE.pdf, s.9,10,15-17 (accessed on: $2 \overline{9} .04 .2020$ )

6] http://jaspedia.eu/wpis/73/fabryka-domow-fadom.htm (accessed on: 8.05.2020) 